\title{
Virulence and antimicrobial resistance characteristics of Vibrio parahaemolyticus isolated from environment, food and clinical samples in the south of Vietnam, 2010
}

\author{
Diep The Tai, Au Vinh Thuy, Nguyen Thi Ngoc Nhi, Nguyen Thi Kim Ngoc, Nguyen Thi Phuong Lan
}

From Institut Pasteur International Network Annual Scientific Meeting

Hong Kong. 22-23 November 2010

\section{Background}

Vibrio parahaemolyticus is a major cause of food poisoning in many countries. The rapid cases of this agent in recent years made it become an important etiology. However, the relationship between strains isolated from environment, food and clinical samples is still unclear. The presence of antimicrobial resistance and virulence factors such as tdh (thermostable direct hemolysin), trh (the TDH - related hemolysin) are proven to be candidate markers for studying on Vibrio parahaemolyticus. In Vietnam, the existence of Vibrio parahaemolyticus is poorly understood. Our objective was to analyse the presence of Vibrio parahaemolyticus from different sources of samples as well as its virulent factors (tdh and trh genes) and antibiotic resistance characteristics.

\section{Methods}

817 samples (food: 85 , water: 299 , stool of acute diarrhea: 433) were collected from May to July, 2010 at Ho Chi Minh City, Can Tho City, Ca Mau, Ben Tre, An Giang and Bac Lieu provinces from Southern of Vietnam. All samples were cultured and bacterial identified by API 20E. Besides, PCR for ToxR gene was performed for confirmation of Vibrio parahaemolyticus. The presence of either tdh or trh gene were done as described previously. Diffusion agar method and MIC were used for screening the antibiotic susceptibility of all identified strains.

\section{Results}

$15.91 \%$ (130/817) Vibrio parahaemolyticus was isolated including 8.3\% (36/434) from acute diarrheal patients, $40 \%(34 / 85)$ from foods and $20.1 \%$ (60/299) from environment samples. All strains had ToxR gene, but not for tdh and trh genes. In patient, just only $22.2 \%(8 / 36)$ strains had tdh gene and $19.4 \%(7 / 36)$ strains got trh gene. All isolated strains from food were negative with both of thh and trh gene. To trains isolated from environment, the presence of trh gene is $33.3 \%(20 / 60)$ and all of them got negative with tdh gene. To susceptibility test, most of strains was sensitive with tetracycline (90.77\%, MIC $\geq 0.5 \mu \mathrm{g} / \mathrm{ml}$ ), chloramphenicol $(97,69 \%$, MIC $\geq 4 \mu \mathrm{g} / \mathrm{ml}$ ), ciprofloxacin (100\%, MIC $\geq 0.125 \mu \mathrm{g} /$ $\mathrm{ml})$, bactrim, doxycycline $(93.08 \%)$ and resistance with ampicillin $(34.62 \%, \mathrm{MIC} \geq 16 \mu \mathrm{g} / \mathrm{ml})$, tetracycline and bactrim (6.92\%), chloramphenicol, doxycycline $(2.31 \%$ and $4.62 \%$ ) respectively; reduced susceptibility was detected in Vibrio parahaemolyticus for ampicillin $(45.38 \%)$, tetracycline, doxycycline $(2.31 \%)$.

\section{Conclusion}

The circulation of Vibrio parahaemolyticus was quite high in the south of Vietnam. Virulence genes (tdh, trh) are not the only factors to cause diarrhea, we need to

Pasteur Institute of Ho Chi Minh City, Vietnam

Full list of author information is available at the end of the article

(c) 2011 The Tai et al; licensee BioMed Central Ltd. This is an open access article distributed under the terms of the Creative Commons Attribution License (http://creativecommons.org/licenses/by/2.0), which permits unrestricted use, distribution, and reproduction in any medium, provided the original work is properly cited. 
find another virulence factors. Most of isolated strains were sensitive with antibiotic except ampicillin.

Published: 10 January 2011

doi:10.1186/1753-6561-5-S1-P94

Cite this article as: The Tai et al.: Virulence and antimicrobial resistance characteristics of Vibrio parahaemolyticus isolated from environment, food and clinical samples in the south of Vietnam, 2010. BMC Proceedings 20115 (Suppl 1):P94.

Submit your next manuscript to BioMed Central and take full advantage of:

- Convenient online submission

- Thorough peer review

- No space constraints or color figure charges

- Immediate publication on acceptance

- Inclusion in PubMed, CAS, Scopus and Google Scholar

- Research which is freely available for redistribution 